\title{
$\angle$ Research Square \\ Factors affecting birthweight decline in recent Japan based on birth certificates
}

\section{Noriko Kato ( $\sim$ kato.n.aa@niph.go.jp)}

Jumonji Gakuen Joshi Daigaku Jumonji Gakuen Joshi Daigaku Tanki Daigakubu https://orcid.org/00000002-5715-214X

Catherine Sauvaget

National Institute of Public Health

Honami Yoshida

Kanagawa Kenritsu Hoken Fukushi Daigaku Health Innovation Kenkyuka

Tetsuji Yokoyama

National Institute of Public Health

Nobuo Yoshiike

Aomori Kenritsu Hoken Daigaku

Research article

Keywords: birthweight, gestational age, maternal body mass index

Posted Date: November 10th, 2020

DOI: https://doi.org/10.21203/rs.3.rs-44763/v2

License: @ (i) This work is licensed under a Creative Commons Attribution 4.0 International License. Read Full License 


\section{Abstract}

Background: Birthweight has been declining consistently for $>30$ years in Japan. This rapid rise in low birthweight in infants is the worst among the Organization for Economic Co-operation and Development countries.

Objective: To contribute to the literature and provide new information to clarify the risk factors associated with birthweight decline in Japan.

Methods: We used population-based birth certificate data from vital statistics records with prior permission and retrieved 40,968,266 birth certificates of neonates born between 1980 and 2004 to analyze time trends using linear regression analysis for examining whether the decline in birthweight could be explained by obstetrical variables such as gestational age and multiple gestations.

Results: From 1980 to 2004, we observed a decline in mean birthweight with a yearly effect of $-8.07 \mathrm{~g}$, which became steeper after 1985, persisted until 1999, and plateaued thereafter. After adjusting for gestational age, neonatal gender, birth order, multiple gestations, and fathers' age, the yearly effect between 1980 and 2004 reduced to $-5.13 \mathrm{~g}$.

Conclusion: Recent decreases in birthweight among Japanese neonates were not explained fully by trends in gestational age, neonatal gender, birth order, multiple gestations, and fathers' age. Thus, additional factors such as pre-pregnancy maternal body mass index and maternal diet should be considered.

\section{Background}

Birthweight has been declining consistently for more than 30 years in Japan [1]. The mean birthweight in Japan is generally small; it was $3000 \mathrm{~g}$ (3050 g for males and $2960 \mathrm{~g}$ for females) in 2018 [1]. In many countries, the mean birthweight values are relatively high. In 2012, the mean birthweight in England and Wales was 3,316 g [2]; in 2018, it was 3,322 $\mathrm{g}$ in Canada [3] and in 2016, it was 3,200 $\mathrm{g}$ in Korea [4].

In Japan, the proportion of infants with low birth weight (LBW), defined as birthweight $<2,500 \mathrm{~g}$, is high and has been increasing [5] rapidly. The proportion of LBW infants in 1990 and 2018 was $6.3 \%$ and $9.4 \%$, respectively, while that in Canada was $5.5 \%$ and $6.5 \%$, in the UK was $6.7 \%$ and $6.9 \%$ ) and in the USA was $7.2 \%$ and $8.3 \%$, respectively [6]. Due to the rapid increase in the number of LBW infants in Japan, it has been ranked the fifth worst country among the Organization for Economic Co-operation and Development countries [7]. Many countries have also experienced a decline in birthweight in the past few years, including the USA [8], Scandinavian countries [9], and Korea [4], but it is not as dramatic as that in Japan.

Several factors have been identified as reasons for this decline in Japan. Ohmi et al. [10] reported high maternal age (more than thirty years of age), BMI (less than 18.5), and smoking habits as contributing factors. Takimoto et al. [11] reported preterm birth as a major contributing factor. Hence, in 2006, the Ministry of Health, Labour and Welfare (MHLW) in Japan established guidelines regarding optimal gestational weight gain (GWG) of citizens during pregnancy based on pre-pregnancy body mass index (BMI) to guarantee that neonates have an adequate and healthy birthweight of approximately $3000 \mathrm{~g}$ [12]. Additionally, pregnant women are encouraged to consume sufficient nutrients. 
Moreover, in Japan, a national campaign named Healthy Parents and Children 21 began in 2000; improvement of birth weight decline (BWD) was an important target of the campaign. In the final assessment of the first stage of the campaign, BWD had not recovered, indicating that LBW is a severe issue. For the second phase, the improvement of birthweight remains a target. To contribute to the campaign, it is necessary to clarify the modifiable factors affecting birthweight. Hence, we aimed to investigate the period in which the birthweight rapidly decreased and clarify factors contributing to the marked decline.

One of the aims of this study is that birth certificates are not fully ued to clarify the factors affecting BWD. Since birth certificates are gathered from all births in Japan under the Family Register Act and include data on birthweight and other demographic information, we thought that analyzing them might explain the national BWD. Takemoto et al[5]. reported mother age higher than 35 years and preterm birth as risk factors for LBW; however, multivariate analysis is necessary for investigating all the variables included in the birth certificates to determine the factors affecting birthweight.

The incidence of LBW has important public health issues because of its association with increased metabolic syndrome during adulthood, developmental delay, and longer hospital stay in neonates with an increased burden of healthcare costs. In adult life, LBW predisposes individuals to chronic diseases and mortality [13]. Thus, determining the factors associated with BWD over the past few decades in Japan by analyzing birth certificate variables will help provide new insights on the factors established thus far.

\section{Subjects And Methods}

In Japan, birth certificates are stored systematically by the MHLW on electric data files. These certificates are filled by obstetric clinicians or midwives following obstetric recordings in the hospitals or clinics and are filed in the municipalities health departments, which areentered and transformed into electronic files at the MHLW. This database is anonymous and includes information related to neonates gender, birthweight, birth length, gestational age (GA), multiple gestation, parity, fathers' and mothers' age, and birthplace.

With permission from the Statistics and Information Department, Minister's Secretariat, MHLW, a total of 40,968,279 birth certificate files were retrieved between 1980 and 2004 . Before filling in the birth certification form, participants were informed about privacy protection and the use of public welfare data. National registration of vital records such as birth certificates is exhaustive based on the abiding law. Since the research was considered of public interest, it was approved by the MHLW. We used the data from the above mentioned study period because the mean birthweight showed an apparent decline during this period (Figure 1).

From 1980 to 1994, birthweights were recorded to the nearest $100 \mathrm{~g}$, which did not exceed the actual birthweight value. For example, if the measured birthweight was 3,126 g, it was recorded as 3,100 g. Similarly, GA was recorded as completed weeks; for instance, if the actual GA was 38 weeks and 3 days, it was recorded as 38 weeks. To estimate the most probable value assuming that the distribution was uniform through $100-\mathrm{g}$ intervals or 1-week intervals, $50 \mathrm{~g}$ were added to each recorded birthweight value and 0.5 week was added to each recorded GA values.

From 1995 to 2004, birthweight was recorded in actual grams; hence, the recorded unit values were used for analysis. In the same period, GA was recorded as completed weeks and additional days. For linear regression 
analysis, the GA values were converted into weeks; for example, 38 weeks and 3 days was converted into 38 and $3 / 7$ weeks and entered as 38.429 weeks; the values were expressed as whole numbers and decimals for the analysis.

The exact values for fathers' and mothers' age, prefectural number, and delivery number codes were reported. For gestation codes, 1 stands for singletons and 2 stands for multiple births. For gender, 1 stands for male and 2 stands for female.

Among the variables shown in Table 1, those with higher correlation (gender, fathers' age, mothers' age, multiple gestations, main occupation of a household, birth ranking, birthplace, GA, and number of parity times) were calculated as explanatory variables for birthweight. Mothers' age showed a weak positive correlation with birthweight in the linear analysis. To clarify the factors affecting BWD, we used multiple linear regression analysis [14] for all births from 1980 to 2004. P<0.05 was considered statistically significant. All analyses were performed using SAS version 9.1 (SAS Institute, Cary, NC, USA).

The study protocol was approved by the Ethics Committee of the National Institute of Public Health. This study was conducted in accordance with the ethical principles established by the Declaration of Helsinki, 2008.

\section{Results}

From 1980 to 2004, we observed a decrease in birthweight, which became steeper after 1985, persisted until 1999, and plateaued thereafter (Figure 2). Table 1 shows overall correlations with birthweight (1980-2004), which were used to identify variables that could be included in the regression analysis and calculate the means and standard deviations of the variables in 1980 and 2004. From 1980 to 2004, birthweight, GA, and the delivery number decreased, and fathers' and mothers' age increased. The number of gestations got closer to two, indicating that proportion of multiple births had increased. The proportion of neonatal gender was almost stable, and the proportion of multiple births showed a slight increase. Changes in the variables among LBW and preterm birth, which are major birth outcomes associated with BWD, are shown in Tables 2 and 3 . A considerable difference was found in multiple gestations between LBW and non-LBW infants and between preterm and non-preterm infants.

Table 1. Correlation of variables with birthweight (1980-2004) and change in variables between 1980 and 2004 


\begin{tabular}{|c|c|c|c|c|c|c|c|}
\hline \multirow[t]{2}{*}{ variables } & \multirow[t]{2}{*}{ units } & \multicolumn{2}{|c|}{$\begin{array}{l}\text { correlation } \\
\text { birthweight }\end{array}$} & \multicolumn{2}{|c|}{$\begin{array}{l}1980 \\
(\mathrm{n}=1569777)\end{array}$} & \multicolumn{2}{|c|}{$\begin{array}{l}2004 \\
(\mathrm{n}=1110721)\end{array}$} \\
\hline & & $\mathrm{r}^{2}$ & $\mathrm{p}$-value & mean & SD & mean & SD \\
\hline Birthweight & grams & & & 3190 & 444 & 3014 & 441 \\
\hline $\begin{array}{l}\text { Gestational } \\
\text { age }\end{array}$ & weeks & 0.2787 & $<0.0001$ & 39.25 & 1.66 & 38.86 & 2.10 \\
\hline Father age & years of age & 0.0007 & $<0.0001$ & 30.33 & 4.21 & 31.68 & 5.62 \\
\hline Mother age & years of age & 0.0003 & $<0.0001$ & 27.62 & 3.75 & 29.69 & 4.72 \\
\hline $\begin{array}{l}\text { Delivery } \\
\text { number }\end{array}$ & including present birth & 0.0084 & $<0.0001$ & 1.80 & 0.84 & 1.70 & 0.82 \\
\hline $\begin{array}{l}\text { Multiple } \\
\text { gestation }\end{array}$ & $\begin{array}{l}1=\text { singleton } \\
2=\text { multiple birth }\end{array}$ & 0.05 & $<0.0001$ & 1.02 & 0.13 & 1.02 & 0.15 \\
\hline $\begin{array}{ll}\text { live } & \text { birth } \\
\text { number } & \\
\end{array}$ & including present birth & 0.0078 & $<0.0001$ & 1.78 & 0.83 & 1.69 & 0.81 \\
\hline $\begin{array}{l}\text { Neonatal } \\
\text { gender }\end{array}$ & $1=$ male $2=$ female & 0.0086 & $<0.0001$ & 1.49 & 0.50 & 1.49 & 0.50 \\
\hline Year & A.D. & 0.0183 & $<0.0001$ & & & & \\
\hline $\begin{array}{l}\text { Prefecture } \\
\text { number }\end{array}$ & 1 to 47 & 0.0004 & $<0.0001$ & & & & \\
\hline
\end{tabular}

Table 2. Comparison between LBW and non-LBW neonates in 1980 and 2004

\begin{tabular}{|c|c|c|c|c|c|c|c|c|c|}
\hline \multirow[t]{3}{*}{ variables } & \multirow[t]{3}{*}{ units } & \multicolumn{4}{|l|}{1980} & \multicolumn{4}{|l|}{2004} \\
\hline & & \multicolumn{2}{|c|}{$\begin{array}{l}\text { LBW } \\
(\mathrm{n}=81665)\end{array}$} & \multicolumn{2}{|c|}{$\begin{array}{l}\text { non-LBW } \\
(\mathrm{n}=1488112)\end{array}$} & \multicolumn{2}{|c|}{$\begin{array}{l}\text { LBW } \\
(n=104842)\end{array}$} & \multicolumn{2}{|c|}{$\begin{array}{l}\text { non-LBW } \\
(\mathrm{n}=1005130)\end{array}$} \\
\hline & & mean & $\mathrm{SD}$ & mean & $\mathrm{SD}$ & mean & SD & mean & $\mathrm{SD}$ \\
\hline Birthweight & grams & 2156 & 366 & 3246 & 372 & 2158 & 396 & 3103 & 338 \\
\hline $\begin{array}{l}\text { Gestational } \\
\text { age }\end{array}$ & weeks & 36.40 & 3.43 & 39.41 & 1.34 & 36.28 & 3.07 & 39.10 & 1.24 \\
\hline Father age & years of age & 30.34 & 4.61 & 30.33 & 4.19 & 32.07 & 5.81 & 31.64 & 5.60 \\
\hline Mother age & years of age & 27.69 & 4.24 & 27.62 & 3.72 & 30.09 & 4.89 & 29.65 & 4.69 \\
\hline $\begin{array}{l}\text { Delivery } \\
\text { number }\end{array}$ & $\begin{array}{l}\text { including present } \\
\text { birth }\end{array}$ & 1.78 & 0.94 & 1.80 & 0.84 & 1.69 & 0.86 & 1.70 & 0.81 \\
\hline $\begin{array}{l}\text { Multiple } \\
\text { gestation }\end{array}$ & $\begin{array}{l}1=\text { singleton } \\
2=\text { multiple birth }\end{array}$ & 1.03 & 0.16 & 1.00 & 0.07 & 1.17 & 0.38 & 1.01 & 0.08 \\
\hline $\begin{array}{l}\text { Live birth } \\
\text { number }\end{array}$ & $\begin{array}{l}\text { including present } \\
\text { birth }\end{array}$ & 1.75 & 0.91 & 1.78 & 0.82 & 1.68 & 0.85 & 1.69 & 0.81 \\
\hline $\begin{array}{l}\text { Neonatal } \\
\text { gender }\end{array}$ & $1=$ male $2=$ female & 1.53 & 0.50 & 1.48 & 0.50 & 1.54 & 0.50 & 1.48 & 0.50 \\
\hline
\end{tabular}

Table 3. Comparison between preterm and non-preterm neonates in 1980 and 2004

\begin{tabular}{|c|c|c|c|c|c|c|c|c|c|}
\hline \multirow[t]{3}{*}{ variables } & \multirow[t]{3}{*}{ units } & \multicolumn{4}{|l|}{1980} & \multicolumn{4}{|l|}{2004} \\
\hline & & \multicolumn{2}{|c|}{$\begin{array}{l}\text { Preterm } \\
(\mathrm{n}=63821)\end{array}$} & \multicolumn{2}{|c|}{$\begin{array}{c}\text { non-Preterm } \\
(\mathrm{n}=1505946)\end{array}$} & \multicolumn{2}{|c|}{$\begin{array}{l}\text { Preterm } \\
(\mathrm{n}=62935)\end{array}$} & \multicolumn{2}{|c|}{$\begin{array}{c}\text { non-Preterm } \\
(\mathrm{n}=1047338)\end{array}$} \\
\hline & & mean & SD & mean & SD & mean & SD & mean & SD \\
\hline Birthweight & grams & 2396 & 608 & 3223 & 402 & 2191 & 590 & 3063 & 377 \\
\hline $\begin{array}{l}\text { Gestational } \\
\text { age }\end{array}$ & weeks & 34.27 & 2.46 & 39.47 & 1.23 & 34.28 & 2.73 & 39.11 & 1.17 \\
\hline Father age & years of age & 30.70 & 4.78 & 30.31 & 4.19 & 32.49 & 5.95 & 31.63 & 5.59 \\
\hline Mother age & years of age & 28.10 & 4.37 & 27.60 & 3.71 & 30.43 & 5.00 & 29.65 & 4.69 \\
\hline $\begin{array}{l}\text { Delivery } \\
\text { number }\end{array}$ & $\begin{array}{l}\text { including present } \\
\text { birth }\end{array}$ & 1.93 & 1.01 & 1.79 & 0.83 & 1.82 & 0.92 & 1.69 & 0.81 \\
\hline $\begin{array}{l}\text { Multiple } \\
\text { gestation }\end{array}$ & $\begin{array}{l}1=\text { singleton } \\
2=\text { multiple birth }\end{array}$ & 1.03 & 0.18 & 1.01 & 0.09 & 1.22 & 0.41 & 1.01 & 0.10 \\
\hline $\begin{array}{l}\text { live birth } \\
\text { number }\end{array}$ & & 1.89 & 0.98 & 1.78 & 0.82 & 1.80 & 0.91 & 1.68 & 0.80 \\
\hline $\begin{array}{l}\text { Neonatal } \\
\text { gender }\end{array}$ & $1=$ male $2=$ female & 1.43 & 0.50 & 1.49 & 0.50 & 1.44 & 0.50 & 1.49 & 0.50 \\
\hline
\end{tabular}


From 1980 to 2004, we observed a decrease in birthweight with a yearly effect of $-8.07 \mathrm{~g} /$ year. After adjusting for year, gender, fathers' age, multiple gestations, birthplace (prefectural number), GA, and gravidity, the yearly effect of birthweight was $-5.13 \mathrm{~g} /$ year. GA was the most explanatory variable (Table 4).

Table 4. Multivariate analysis with sequential adjustment, according to several time periods

\begin{tabular}{|l|c|c|c|c|c|c|c|c|c|}
\hline All births & \multicolumn{2}{|c|}{$1980-1984$ (early period) } & \multicolumn{3}{|c|}{$1985-1989$} & \multicolumn{3}{|c|}{$1990-1994$} \\
\hline $\begin{array}{l}\text { Yearly } \\
\text { effect }\end{array}$ & $\begin{array}{c}\text { Birth } \\
\text { weight } \\
\text { (g) }\end{array}$ & $\begin{array}{c}\text { Standard } \\
\text { error }\end{array}$ & $\mathrm{r}^{2}$ & $\begin{array}{c}\text { Birth } \\
\text { weight } \\
(\mathrm{g})\end{array}$ & $\begin{array}{c}\text { Standard } \\
\text { error }\end{array}$ & $\mathrm{r}^{2}$ & $\begin{array}{c}\text { Birth } \\
\text { weight } \\
\text { (g) }\end{array}$ & $\begin{array}{c}\text { Standard } \\
\text { error }\end{array}$ & $\mathrm{r}^{2}$ \\
\hline Crude & -3.98 & 0.11 & 0.0002 & -8.50 & 0.12 & 0.0007 & -8.71 & 0.13 & 0.0008 \\
\hline $\begin{array}{l}\text { Adjusted } \\
\text { for } \\
\text { gestational } \\
\text { age }\end{array}$ & -0.07 & 0.10 & 0.2151 & -3.60 & 0.10 & 0.2483 & -7.58 & 0.11 & 0.2843 \\
\hline $\begin{array}{l}\text { Plus } \\
\text { neonatal } \\
\text { gender }\end{array}$ & 0.02 & 0.10 & 0.2289 & -3.53 & 0.10 & 0.2628 & -7.57 & 0.10 & 0.2991 \\
\hline $\begin{array}{l}\text { Plus } \\
\text { delivery } \\
\text { number }\end{array}$ & -0.19 & 0.10 & 0.2441 & -3.42 & 0.10 & 0.2805 & -6.32 & 0.10 & 0.3184 \\
\hline $\begin{array}{l}\text { Plus } \\
\text { multiple } \\
\text { gestation }\end{array}$ & -0.32 & 0.10 & 0.2607 & -3.42 & 0.10 & 0.2948 & -5.97 & 0.10 & 0.3326 \\
\hline $\begin{array}{l}\text { Plus live } \\
\text { birth } \\
\text { number }\end{array}$ & -0.33 & 0.10 & 0.2607 & -3.47 & 0.10 & 0.2948 & -5.97 & 0.10 & 0.3226 \\
\hline $\begin{array}{l}\text { Plus father } \\
\text { age }\end{array}$ & -0.53 & 0.10 & 0.2592 & -3.66 & 0.10 & 0.2936 & -5.99 & 0.10 & 0.3316 \\
\hline
\end{tabular}

\begin{tabular}{|c|c|c|c|c|c|c|c|c|}
\hline All births & \multicolumn{3}{|c|}{ 1995-1999 } & \multicolumn{3}{|c|}{ 2000-2004 (late period) } & \multicolumn{2}{|c|}{$\begin{array}{c}1980-2004 \text { (total } \\
\text { period) }\end{array}$} \\
\hline Yearly effect & $\begin{array}{c}\text { Birth } \\
\text { weight } \\
\text { (g) }\end{array}$ & $\begin{array}{l}\text { Standard } \\
\text { error }\end{array}$ & r2 & $\begin{array}{c}\text { Birth } \\
\text { weight } \\
\text { (g) }\end{array}$ & $\begin{array}{l}\text { Standard } \\
\text { error }\end{array}$ & r2 & $\begin{array}{c}\text { Birth } \\
\text { weight } \\
\text { (g) }\end{array}$ & $\begin{array}{l}\text { Standard } \\
\text { error }\end{array}$ \\
\hline Crude & -7.66 & 0.13 & 0.0006 & -4.84 & 0.13 & 0.0002 & -8.07 & 0.01 \\
\hline $\begin{array}{l}\text { Adjusted for } \\
\text { gestational age }\end{array}$ & -7.01 & 0.10 & 0.3150 & -3.04 & 0.10 & 0.3456 & -5.63 & 0.01 \\
\hline $\begin{array}{l}\text { Plus neonatal } \\
\text { gender }\end{array}$ & -7.02 & 0.10 & 0.3302 & -2.99 & 0.10 & 0.3607 & -5.60 & 0.01 \\
\hline $\begin{array}{l}\text { Plus delivery } \\
\text { number }\end{array}$ & -6.42 & 0.10 & 0.3480 & -2.96 & 0.10 & 0.3754 & -5.16 & 0.01 \\
\hline $\begin{array}{l}\text { Plus multiple } \\
\text { gestation }\end{array}$ & -6.28 & 0.10 & 0.3621 & -2.79 & 0.10 & 0.3884 & -5.06 & 0.01 \\
\hline $\begin{array}{l}\text { Plus live birth } \\
\text { number }\end{array}$ & -6.28 & 0.10 & 0.3621 & -2.79 & 0.10 & 0.3884 & -5.07 & 0.01 \\
\hline Plus father age & -6.26 & 0.10 & 0.3613 & -2.87 & 0.10 & 0.3872 & -5.13 & 0.01 \\
\hline
\end{tabular}

In the early period between 1980 and 1984, the decrease in birthweight was relatively small. The crude yearly effect was -3.98 g/year, and it became -0.53 g/year after adjustment. In 1985-1989, 1990-1994, and 19951999 , the decrease became steeper. The crude yearly effect was $-8.50,-8.71$, and $-7.66 \mathrm{~g} / \mathrm{year}$, respectively, 
which became $-3.66,-5.99$, and $-6.26 \mathrm{~g} / \mathrm{year}$ after adjustment. In the late period between 2000 and 2004 , the decrease in birthweight had declined. The crude yearly effect was $-4.84 \mathrm{~g} / \mathrm{year}$, which reduced to $-2.87 \mathrm{~g} / \mathrm{year}$ after adjustment. In 1980-1984, 1985-1989, and 2000-2004, GA accounted for the most important determinant, while in 1990-1994 and 1995-1999, GA accounted for nearly half of the explained variables.

\section{Discussion}

From 1980 to 2004, the mean birthweight decreased in Japan, specifically between 1985 and 1999. Although 2004 was 16 years ago, the birthweight trend was almost constant after the peak. Using data of years in which the BWD was rapid and precise would provide further insight into possible factors contributing to the decline in LBW through multiple regression analysis. However, based on our analyses, the decline was not fully explained by adjusting variables obtained from birth certificates.

Some studies have examined birthweight changes among subgroups, for example, first-birth singletons [8]. As expected, the BWD was mainly associated with gestational age in the multivariable regression analysis. After adjusting for all variables used in the multiple regression analysis, the decrease in birthweight was $5.13 \mathrm{~g} / \mathrm{year}$ compared to a crude reduction of $8.07 \mathrm{~g} / \mathrm{year}$. GA is not the only factor responsible for the entire birthweight decline. Indeed, Morisaki et al. [15] reported birthweight decreases in the USA, regardless of GA.

In this study, we used large, nationally representative data that would not change for decades and we had the necessary information on potential factors associated with trends in birthweight.

One of the limitations of this study was GA estimation. GA was entered in the birth certificate by doctors or midwives in hospitals or clinics. Some were based on the date of the last normal menstrual period, while others were based on early fetal ultrasonography. This might introduce variability and affect the validity of our GA estimation. Schonberg et al. [16] determined that GA calculated from the last menstrual period is reasonably accurate among term births.

Many factors affect birthweight; however, the following factors were not analyzed in this study: medical conditions in pregnancy, childbirth, and other modifiable factors, such as pregnancy diabetes, pregnancy hypertension, placental abruption and abnormal obstetric bleeding. Considering obstetrical practice, GA is affected by the mode of delivery. The induction of labor has also steadily increased in Japan [17]. Based on the national growth survey, the rates of cesarean deliveries have increased from $19 \%$ in 2000 up to $25 \%$ in 2010 [18]. These factors might cause a decline in GA. Data from the USA showed that a decrease in GA is affected by an increase in the number of induced labor [8].

Another limitation of this study is the lack of data likely associated with birthweight, such as maternal smoking status, pre-pregnancy weight, and maternal diet during pregnancy. Our data did not provide information on medical conditions such as diabetes and hypertension, which affect birthweight by causing large GA neonates and fetal growth restrictions, leading to LBW. Maternal smoking restricts fetal growth and increases obstetrical complications and the risk of preterm birth; these factors are likely to induce LBW and even stillbirths [19].

In Japan, $5.0 \%, 10.0 \%$, and $5.0 \%$ of pregnant women smoked in 1990, 2000, and 2010, respectively [20]. Moreover, in a recent survey on mothers and children aged 3-4 months, LBW was significantly associated with 
maternal smoking [21]. A decrease in the proportion of pregnant women who smoked could be a cause of decrease in birthweight after 2000. In Japan, the Health Promotion Law was enforced in 2002, and people were encouraged to quit smoking thereafter. In Canada, intervention studies on pregnant women, including studies on health education about the adverse effects of smoking, decreased the proportion of LBW [22].

Pre-pregnancy BMI and GWG are factors that affect birthweight [23]. Information on maternal pre-pregnancy weight was not included in our data. BMI distribution among women within reproductive age could be a proxy for pre-pregnant BMI. The prevalence of underweight has been increasing over the decades in Japan, contrasting with other countries [24]. According to the National Health and Nutrition Survey [25], the proportion of women with a BMl of less than $18.5 \mathrm{~kg} / \mathrm{m}^{2}$ in the age group of 20-39 years is increasing concomitantly with a decline in the mean birthweight (Figure 2). For the discussion of causality between maternal BMI and birthweight, further studies are needed.

Our data also did not include maternal diet, which might affect fetal growth. In Japan, the National Health and Nutrition Survey has revealed synchronized time trends for per capita calorie intake (Figure 3); however, the causality is still unclear.

Time-trend synchronization was suggested between birthweight and BMI in women of reproductive age and birthweight and energy intake of the whole population. The decline in energy intake of the entire population is a reflection of the decrease in macronutrient intake in pregnant women, which is likely to correlate with LBW. These factors other than GA can most likely result in LBW and their effect may be more substantial than that of $\mathrm{GA}$.

Another factor suggested to increase the prevalence of LBW in Japan is the decline in adult height [26]. An increase in maternal age [27] has been shown to be a factor associated with decreased birthweight in Korea. In our study, maternal age did not show a linear correlation with birthweight and could not be included as an explanatory variable. Another maternal condition that lowers birthweight is anemia and parasitic infections. In Pakistan, the relationship between iron-deficiency anemia and LBW was identified [28], and in Sudan [29], the effects of maternal malaria on LBW have been reported. Among Japanese mothers living in urban area, hemoglobin change during pregnancy was inversely associated with birthweight.[30]

Although socioeconomic status is a well-known factor affecting birthweight [31], birth certificates do not contain any variable which allow analysis related to this factor. A comparison of secular trends of economic growth[32-34] and mean birthweight in Japan is shown in Figure 4. Although the timings of deterioration in economic growth and birthweight are almost the same, the synchronization is unclear. Yorifuji et al. [35] pointed out that socioeconomic position is related to air pollution, which influences the occurrence of LBW in Japan, suggesting the importance of socioeconomic factors.

Further, climate affects birth outcomes; in a study including 32 million US singletons [36], extremely high temperature was associated with preterm birth, which has a strong correlation with LBW. In the Japanese setting, urbanization has caused long-term climate changes related to a rise in temperature [37]. Thus, such factors should also be considered. 
In this study, we aimed to provide further insights on factors contributing to LBW through the analysis of variables contained in birth certificates in Japan. By analyzing neonates born from 1980 to 2004, decreases in birthweight were not fully explained by factors included in the birth certificates. A decrease in GA only partially explained the decreasing birthweight. Birth size might influence not only short-term conditions but also longterm prognosis [13]. Factors lowering birthweight, although not analyzed fully in the present study, could cause various health problems among children as they grow up and even in their adult lives. Therefore, a follow-up study is necessary to investigate which sequalae would derive from LBW neonates.

In conclusion, our study based on data from birth certificates showed that infants' birthweights have decreased over the decades. These findings might partially be explained by the decline in GA, considered to result from a change in the mode of delivery. Thus, further studies are needed to determine the clinical and social significance of these findings.

\section{List Of Abbreviations}

MHLW: Ministry of Health, Labour and Welfare

GA: gestational age

LBW: low birth weight

GWG: gestational weight gain

BWD: birthweight decline

\section{Declarations}

\section{Ethics approval and consent to participate}

The protocol of the present study was approved by the Ethics Committee of the National Institute of Public Health (Approval no. NIPH-IRBA \#12010).

\section{Consent for publication}

Not applicable

\section{Availability of data and materials}

The data were provided by the Statistics and Information Department of the Minister's Secretariat at the Ministry of Health, Labor, and Welfare with permission from the Ministry. The data could be obtained if claimed and permitted.

\section{Competing interests}

None

Funding 
This study was supported financially by a grant from the Ministry of Health, Labor, and Welfare (H16-kodomoippan-033 and H30-sukoyaka-shitei-001).

\section{Authors' contributions}

All authors contributed substantially to the publication. NK contributed to the literature search, study design, data collection, data interpretation, and writing. CS contributed to data analysis, data interpretation, and writing. HY contributed to data interpretation and writing. TY supervised the execution of the study, data interpretation, and writing. NY supervised the design of the study, data interpretation, and writing

\section{Acknowledgment}

We thank the staff of the Statistics and Information Department of the Minister's Secretariat at the Ministry of Health, Labor and Welfare for arranging the dataset for the present study.

\section{References}

1. Annual report on vital statistics. In: Minister's Secretariat Statistics Information Department. accessed 2020.7.8 edn: https://www.mhlw.go.jp/toukei/list/81-1a.html.

2. Ghosh RE, Berild JD, Sterrantino AF, Toledano MB, Hansell AL: Birth weight trends in England and Wales (1986-2012): babies are getting heavier. Arch Dis Child Fetal Neonatal Ed 2018, 103(3):F264-F270.

3. Statistics Canada. In: Canada's national statistical agency. accessed 2020.7.8 edn: https://www150.statcan.gc.ca/t1/tbl1/en/tv.action?pid=1310042301.

4. Kim HE, Song IG, Chung SH, Choi YS, Bae CW: Trends in Birth Weight and the Incidence of Low Birth Weight and Advanced Maternal Age in Korea between 1993 and 2016. J Korean Med Sci 2019, 34(4):e34.

5. Takemoto Y, Ota E, Yoneoka D, Mori R, Takeda S: Japanese secular trends in birthweight and the prevalence of low birthweight infants during the last three decades: A population-based study. Sci Rep 2016, 6:31396.

6. OECD Health Statistics 2020. In: OECD Stat. accessed 2020.7.8 edn: https://stats.oecd.org/Index.aspx? ThemeTreeld $=9$.

7. OECD Family Database C01.3: Low birth weight. In: OECD statistics. accessed 2020.7.8 edn: https://www.oecd.org/els/family/CO_1_3_Low_birth_weight.pdf; 2019.

8. Tilstra AM, Masters RK: Worth the Weight? Recent Trends in Obstetric Practices, Gestational Age, and Birth Weight in the United States. Demography 2020, 57(1):99-121.

9. Carlsen EO, Magnus MC, Omsland TK, Magnus PM, Haberg SE, Wilcox AJ: Stumped by the Hump: The Curious Rise and Fall of Norwegian Birthweights, 1991-2007. Epidemiology 2020, 31(4):587-594.

10. Ohmi H, Hirooka K, Hata A, Mochizuki Y: Recent trend of increase in proportion of low birthweight infants in Japan. International journal of epidemiology 2001, 30(6):1269-1271.

11. Takimoto H, Yokoyama T, Yoshiike N, Fukuoka H: Increase in low-birth-weight infants in Japan and associated risk factors, 1980-2000. J Obstet Gynaecol Res 2005, 31(4):314-322.

12. Takimoto H, Sugiyama T, Fukuoka H, Kato N, Yoshiike N: Maternal weight gain ranges for optimal fetal growth in Japanese women. Int J Gynaecol Obstet 2006, 92(3):272-278. 
13. Suzuki K: The developing world of DOHaD. J Dev Orig Health Dis 2018, 9(3):266-269.

14. Kramer MS, Morin I, Yang H, Platt RW, Usher R, McNamara H, Joseph KS, Wen SW: Why are babies getting bigger? Temporal trends in fetal growth and its determinants. The Journal of pediatrics 2002, 141(4):538542.

15. Morisaki N, Esplin MS, Varner MW, Henry E, Oken E: Declines in birth weight and fetal growth independent of gestational length. Obstetrics and gynecology 2013, 121(1):51-58.

16. Schonberg D, Wang LF, Bennett AH, Gold M, Jackson E: The accuracy of using last menstrual period to determine gestational age for first trimester medication abortion: a systematic review. Contraception 2014, 90(5):480-487.

17. Terada M, Matsuda Y, Ogawa M, Matsui H, Satoh S: Effects of maternal factors on birth weight in Japan. Journal of pregnancy 2013, 2013:172395.

18. Kato N, Takimoto H, Yokoyama T, Yokoya S, Tanaka T, Tada H: Updated Japanese growth references for infants and preschool children, based on historical, ethnic and environmental characteristics. Acta paediatrica 2014, 103(6):e251-e261.

19. Abraham M, Alramadhan S, Iniguez C, Duijts L, Jaddoe VW, Den Dekker HT, Crozier S, Godfrey KM, Hindmarsh P, Vik T et al: A systematic review of maternal smoking during pregnancy and fetal measurements with meta-analysis. PLoS One 2017, 12(2):e0170946.

20. Summary of the national growth survey on preschool children. In: Equal Employment, Children and Families Bureau, Ministry of Health, Labour and Welfare. accessed 2020.7.8 edn:

http://www.mhlw.go.jp/toukei/list/73-22b.html.

21. Ooka T, Akiyama Y, Shinohara R, Yokomichi H, Yamagata Z: Individual and Regional Characteristics Associated with Maternal Smoking During Pregnancy in Japan: Healthy Parents and Children 21. Int J Environ Res Public Health 2019, 17(1).

22. Kuhle S, Maguire B, Zhang H, Hamilton D, Allen AC, Joseph KS, Allen VM: Comparison of logistic regression with machine learning methods for the prediction of fetal growth abnormalities: a retrospective cohort study. BMC Pregnancy Childbirth 2018, 18(1):333.

23. Papazian T, Abi Tayeh G, Sibai D, Hout H, Melki I, Rabbaa Khabbaz L: Impact of maternal body mass index and gestational weight gain on neonatal outcomes among healthy Middle-Eastern females. PLoS One 2017, 12(7):e0181255.

24. Ziauddeen N, Wilding S, Roderick PJ, Macklon NS, Alwan NA: Is maternal weight gain between pregnancies associated with risk of large-for-gestational age birth? Analysis of a UK population-based cohort. BMJ Open 2019, 9(7):e026220.

25. Annual report on national health and nutrition survey. In: Health Service Division, Minister of Health, Labour and Welfare. acccessed 2020.7 .8 edn: https://www.mhlw.go.jp/bunya/kenkou/kenkou_eiyou_chousa.html.

26. Morisaki N, Urayama KY, Yoshii K, Subramanian SV, Yokoya S: Ecological analysis of secular trends in low birth weight births and adult height in Japan. J Epidemiol Community Health 2017, 71(10):1014-1018.

27. Sohn K: The trend in the relationship of advanced maternal age to preterm birth and low birthweight. Eur $J$ Contracept Reprod Health Care 2017, 22(5):363-368. 
28. Mahmood T, Rehman AU, Tserenpil G, Siddiqui F, Ahmed M, Siraj F, Kumar B: The Association between Iron-deficiency Anemia and Adverse Pregnancy Outcomes: A Retrospective Report from Pakistan. Cureus 2019, 11(10):e5854.

29. Taha Tel T, Gray RH, Mohamedani AA: Malaria and low birth weight in central Sudan. Am J Epidemiol 1993, 138(5):318-325.

30. Jwa SC, Fujiwara T, Yamanobe Y, Kozuka K, Sago H: Changes in maternal hemoglobin during pregnancy and birth outcomes. BMC Pregnancy Childbirth 2015, 15:80.

31. Chung $\mathrm{H}$, Muntaner $\mathrm{C}$ : Political and welfare state determinants of infant and child health indicators: an analysis of wealthy countries. Soc Sci Med 2006, 63(3):829-842.

32. System of national accounts based on 1990. In: Cabinet Office. accessed 2020.10.19 edn: https://www.esri.cao.go.jp/jp/sna/data/data_list/kakuhou/files/h10/12annual_report_j.html.

33. System of national accounts based on 2000. In: Cabinet Office. accessed 2020.10.19 edn: https://www.esri.cao.go.jp/jp/sna/data/data_list/kakuhou/files/h21/h21_kaku_top.html.

34. System of national accounts based on 2011. In: Cabinet Office. accessed 2020.10.19 edn: https://www.esri.cao.go.jp/jp/sna/data/data_list/kakuhou/files/h30/h30_kaku_top.html.

35. Yorifuji T, Naruse H, Kashima S, Takao S, Murakoshi T, Doi H, Kawachi I: Residential proximity to major roads and adverse birth outcomes: a hospital-based study. Environ Health 2013, 12(1):34.

36. Sun S, Weinberger KR, Spangler KR, Eliot MN, Braun JM, Wellenius GA: Ambient temperature and preterm birth: A retrospective study of 32 million US singleton births. Environ Int 2019, 126:7-13.

37. Matsumoto J, Fujibe F, Takahashi H: Urban climate in the Tokyo metropolitan area in Japan. J Environ Sci (China) 2017, 59:54-62.

\section{Figures}




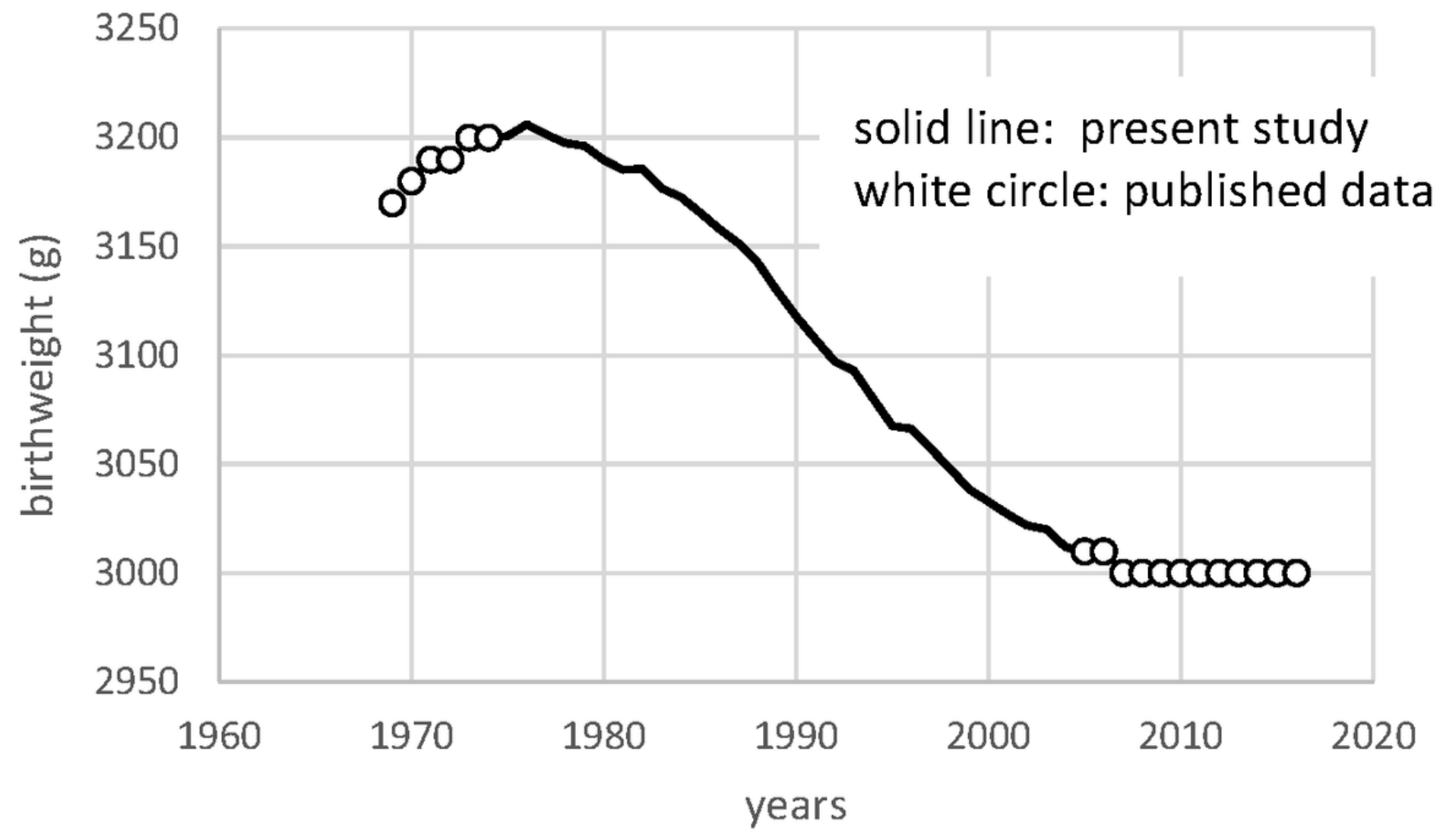

Figure 1

Secular trend of mean birthweight Published data is from Annual report of vital statistics of Japan (reference 1) 


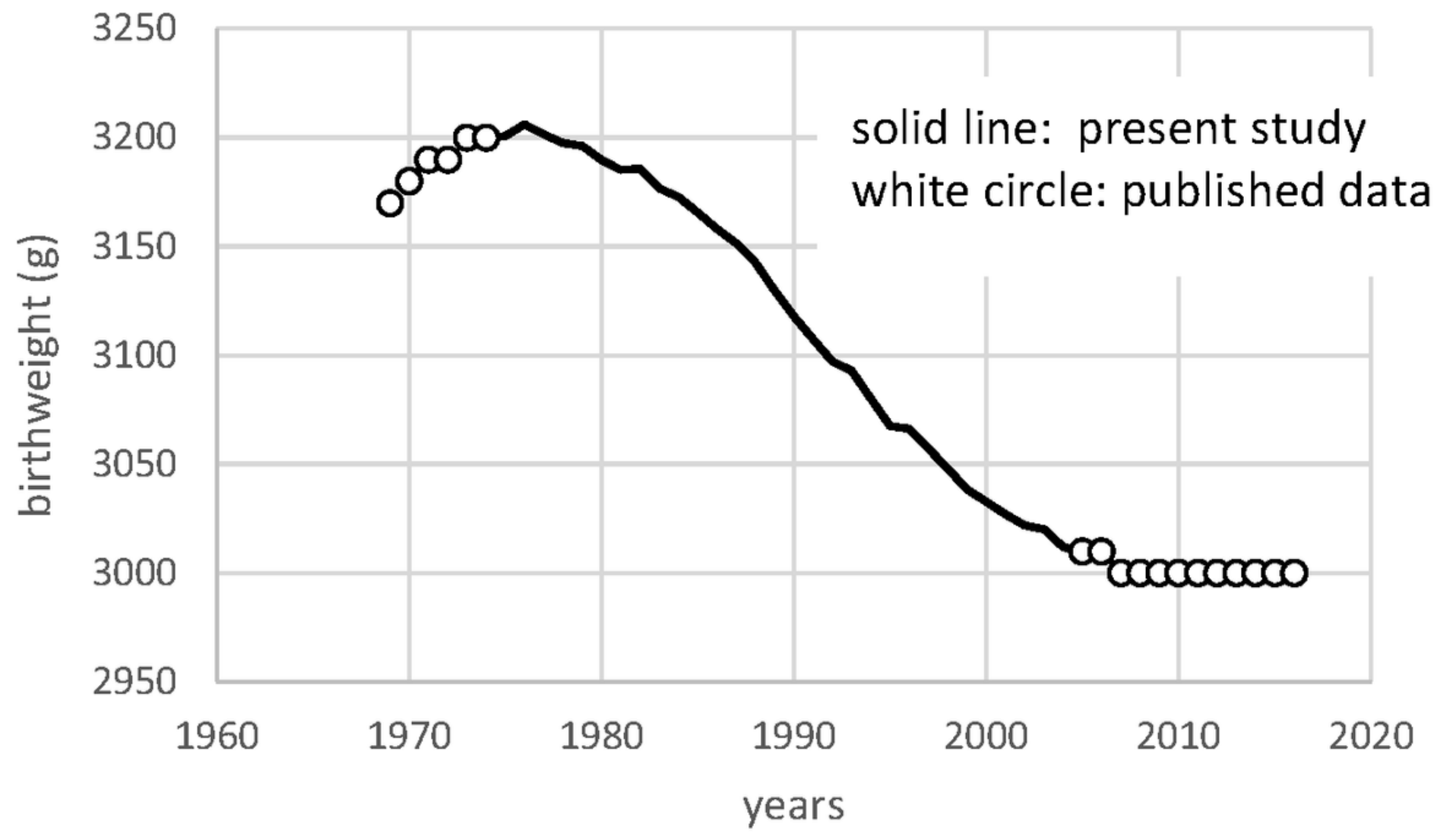

Figure 1

Secular trend of mean birthweight Published data is from Annual report of vital statistics of Japan (reference 1) 


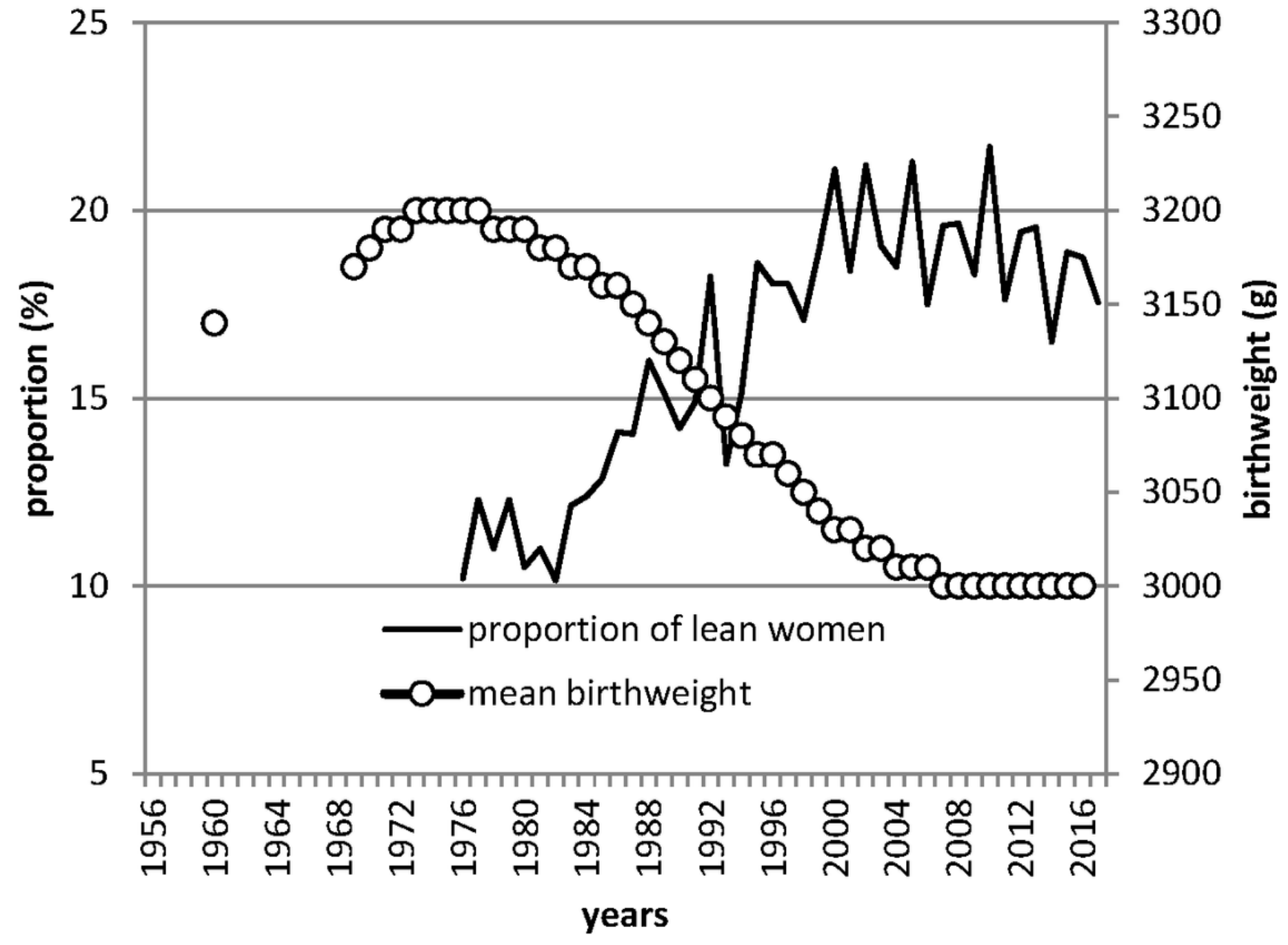

Figure 2

Secular trends of proportion of lean women and mean birthweight Mean birthweight is from Annual report of vital statistics of Japan (reference 1) Proportion lean woman means proportion of woman under BMI of 18.5 aged between 20 to 39 years, which are calculated from Annual Report of Health and Nutrition (reference 32) 


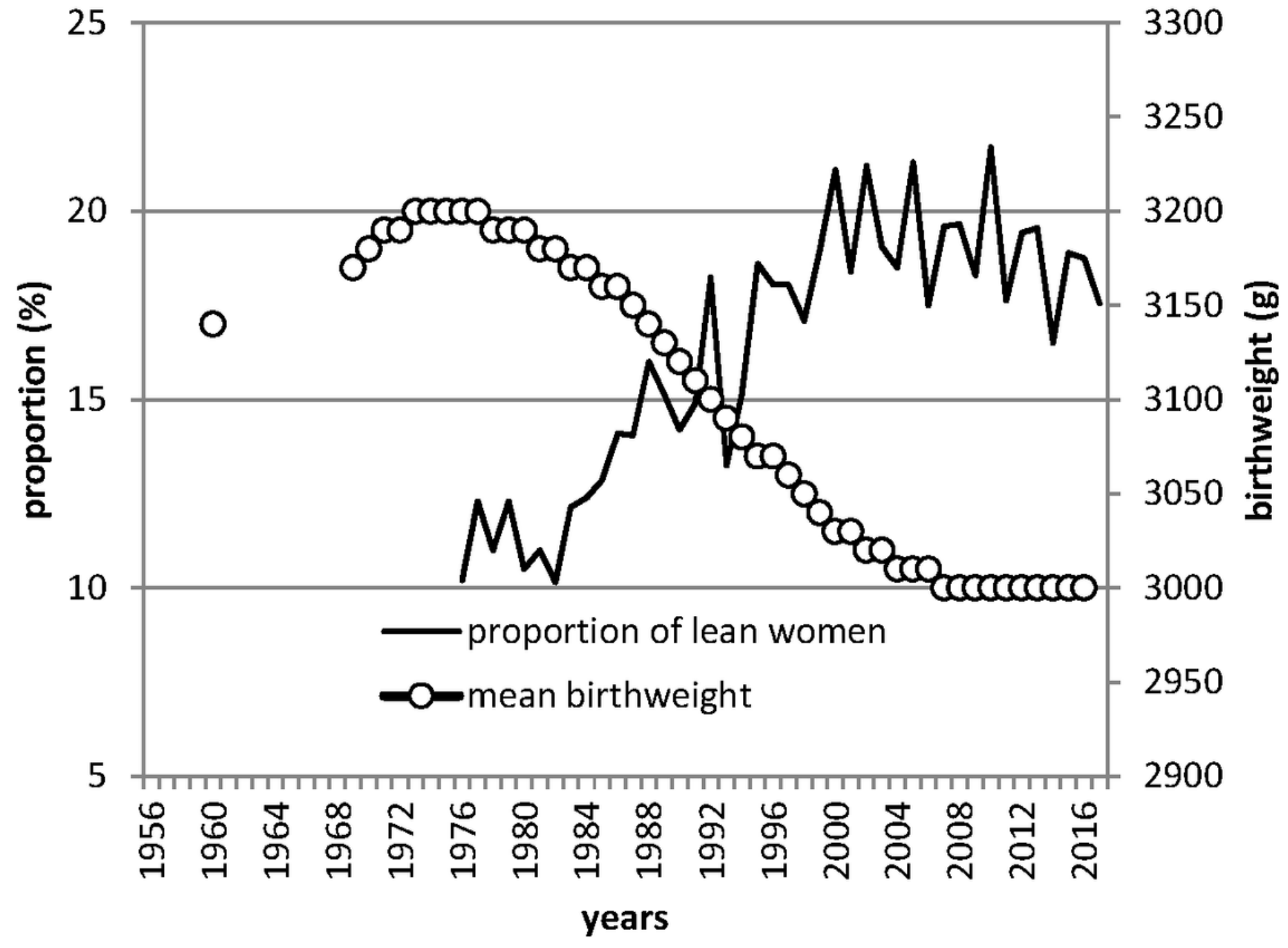

Figure 2

Secular trends of proportion of lean women and mean birthweight Mean birthweight is from Annual report of vital statistics of Japan (reference 1) Proportion lean woman means proportion of woman under BMI of 18.5 aged between 20 to 39 years, which are calculated from Annual Report of Health and Nutrition (reference 32) 


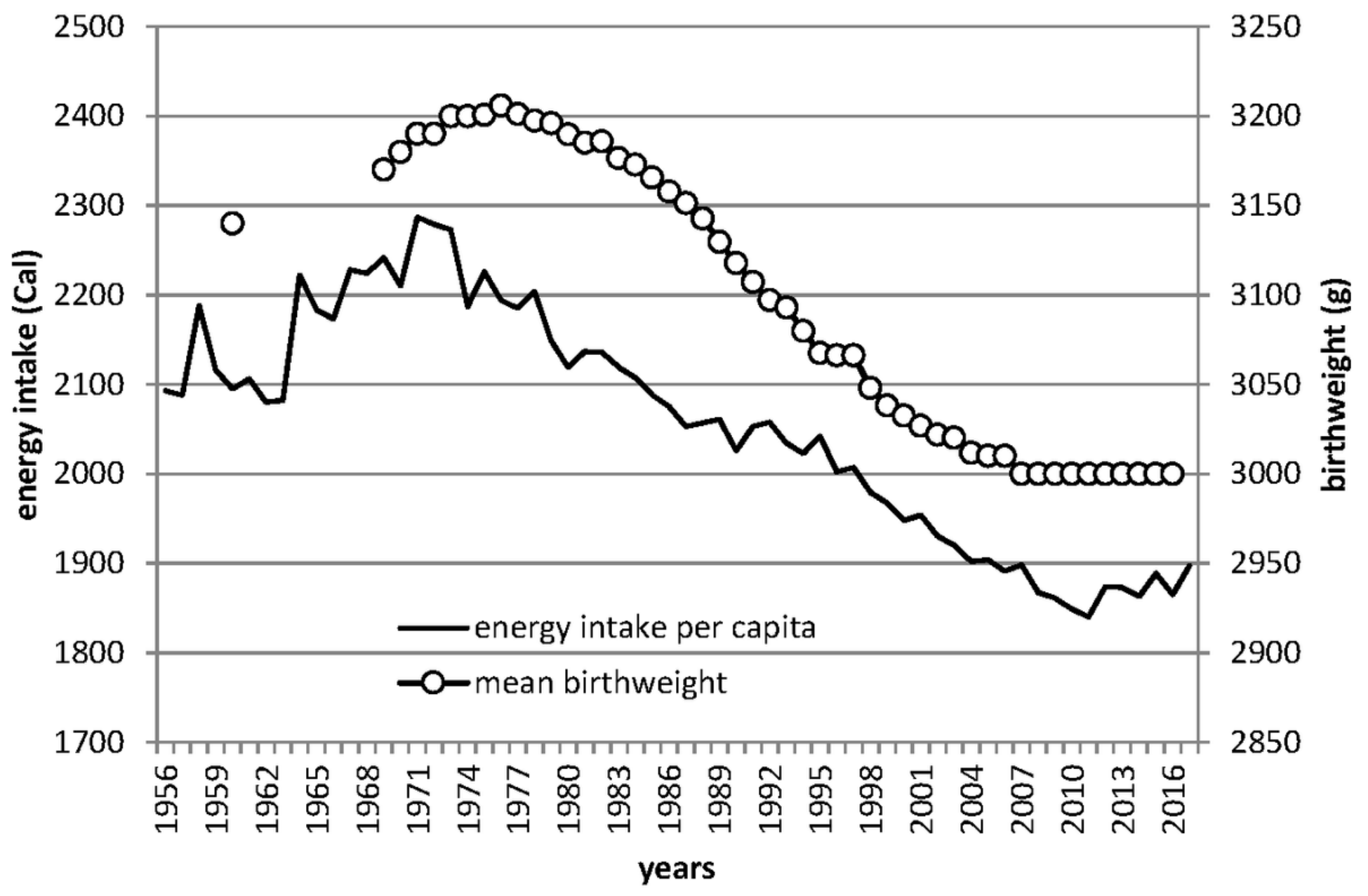

Figure 3

Secular trends of calorie intake per capita (both male and female) and mean birthweight Mean birthweight is from Annual report of vital statistics of Japan (reference 1) Calorie intake per capita is from Annual Report of Health and Nutrition (reference 32) 


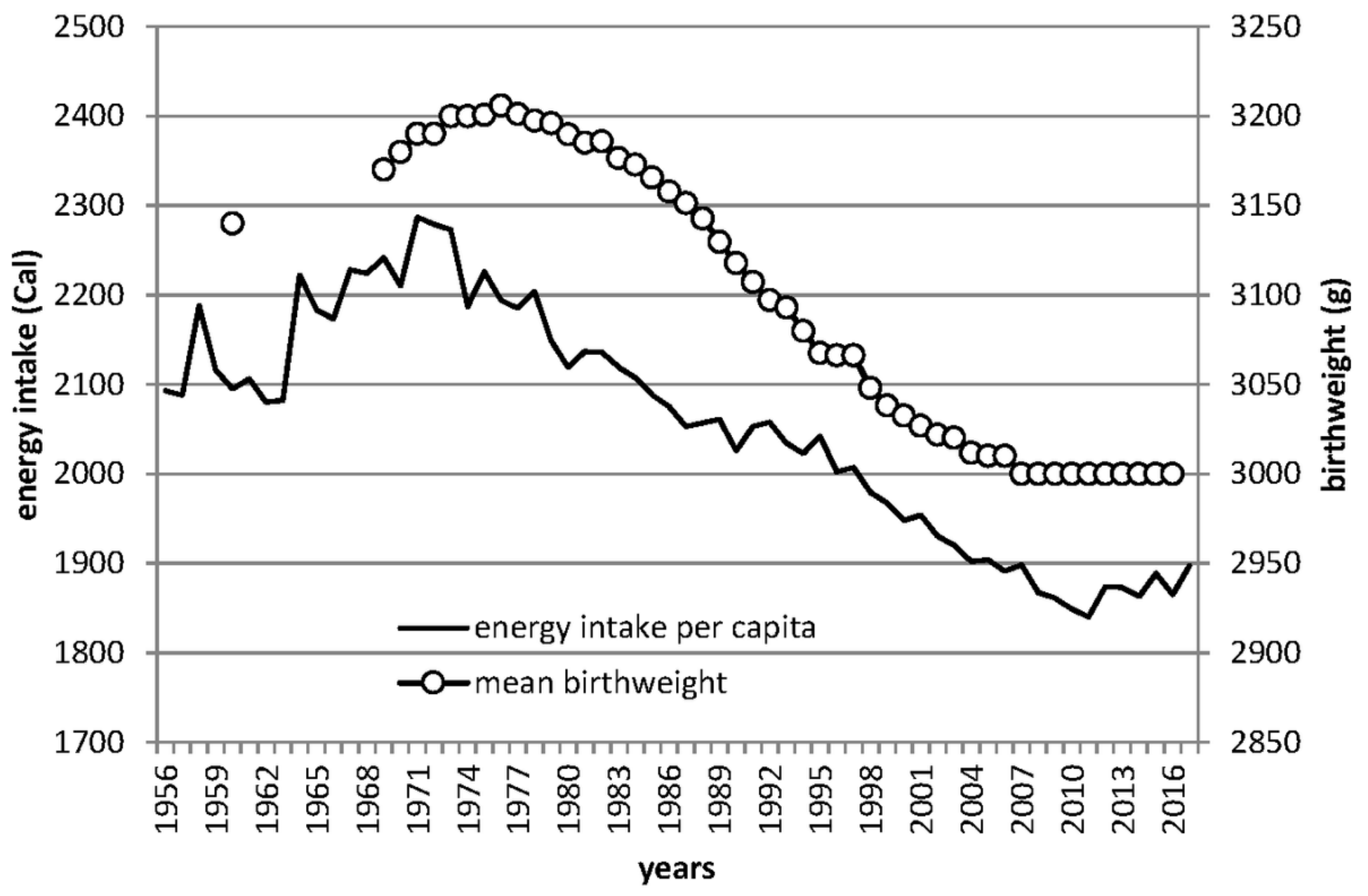

Figure 3

Secular trends of calorie intake per capita (both male and female) and mean birthweight Mean birthweight is from Annual report of vital statistics of Japan (reference 1) Calorie intake per capita is from Annual Report of Health and Nutrition (reference 32) 


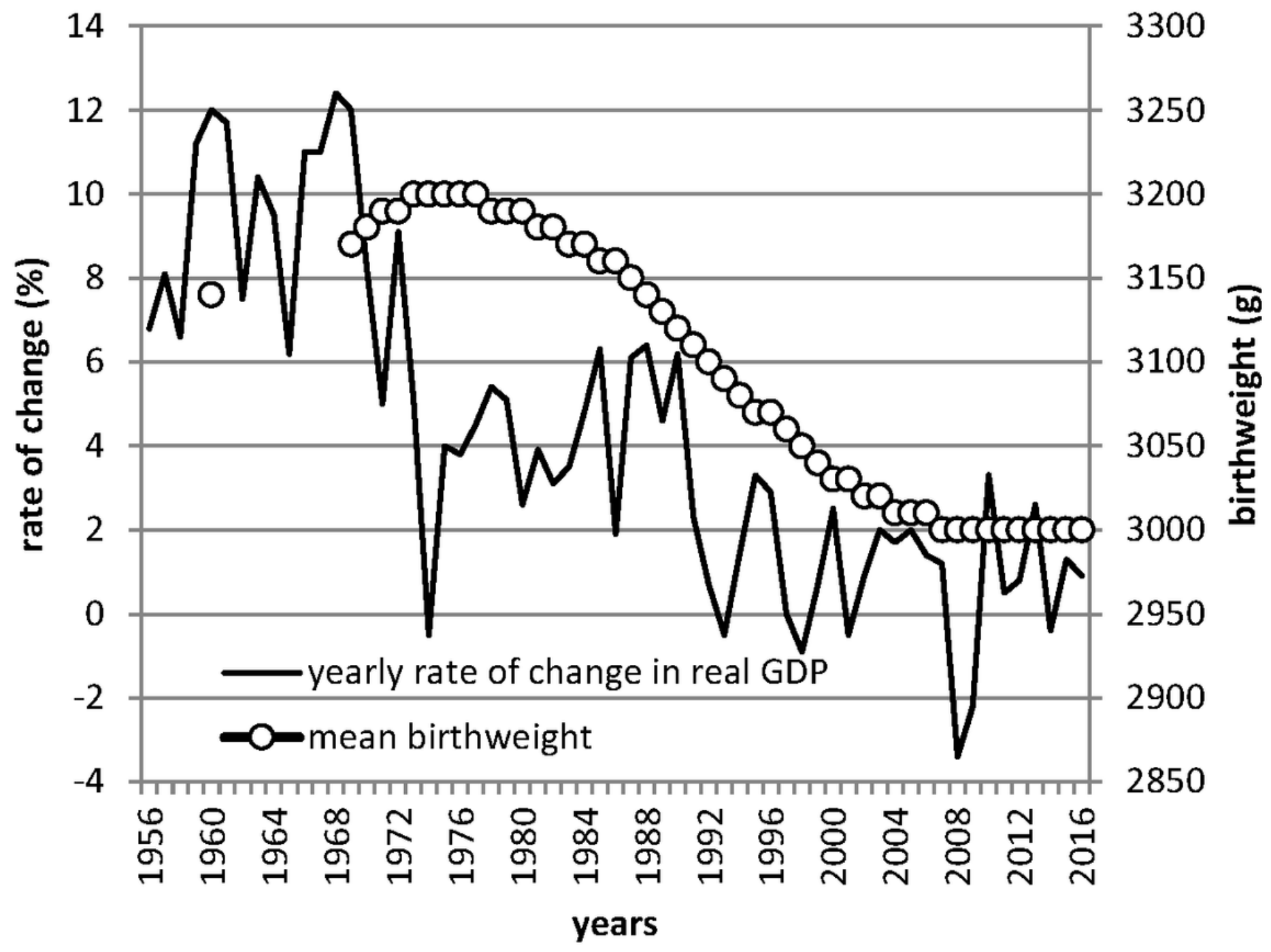

Figure 4

Secular trends of yearly change in GDP and mean birthweight. Mean birthweight is from Annual report of vital statistics of Japan (reference 1). Yearly change in GDP is from System of national accounts (reference 32-34). 


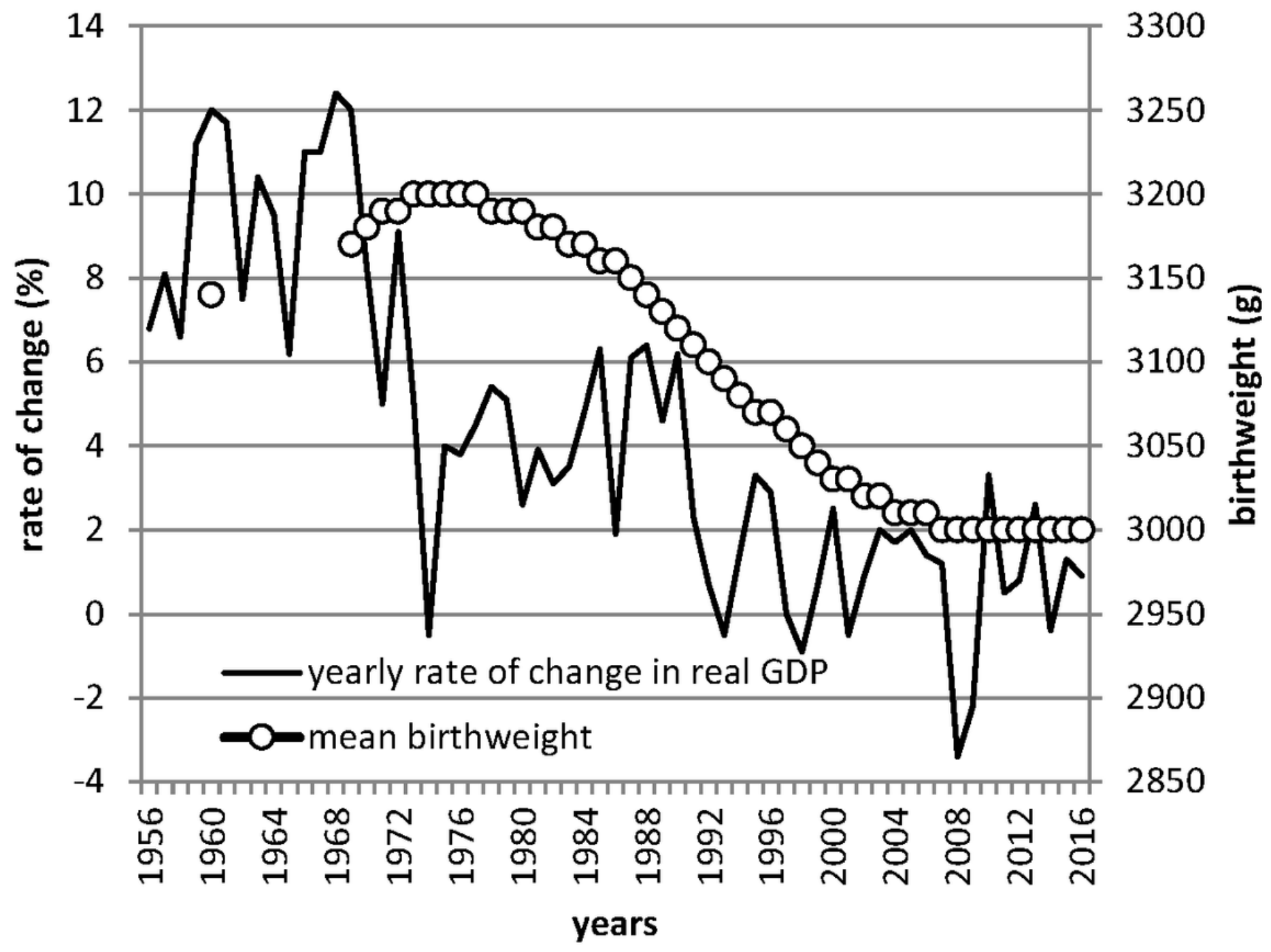

Figure 4

Secular trends of yearly change in GDP and mean birthweight. Mean birthweight is from Annual report of vital statistics of Japan (reference 1). Yearly change in GDP is from System of national accounts (reference 32-34). 